\title{
Sexual transmission of human T-cell lymphotropic virus type 1
}

\author{
Arthur Paiva $^{[1]}$ and Jorge Casseb ${ }^{[1]}$
}

[1]. Laboratório de Investigação em Dermatologia e Imunodeficiência, Instituto de Medicina Tropical de São Paulo, Universidade de São Paulo, São Paulo, SP.

\begin{abstract}
Human T-cell lymphotropic virus type 1 (HTLV-1) is endemic in many parts of the world and is primarily transmitted through sexual intercourse or from mother to child. Sexual transmission occurs more efficiently from men to women than women to men and might be enhanced by sexually transmitted diseases that cause ulcers and result in mucosal ruptures, such as syphilis, herpes simplex type 2 (HSV-2), and chancroid. Other sexually transmitted diseases might result in the recruitment of inflammatory cells and could increase the risk of HTLV-1 acquisition and transmission. Additionally, factors that are associated with higher transmission risks include the presence of antibodies against the viral oncoprotein Tax (anti-Tax), a higher proviral load in peripheral blood lymphocytes, and increased cervicovaginal or seminal secretions. Seminal fluid has been reported to increase HTLV replication and transmission, whereas male circumcision and neutralizing antibodies might have a protective effect. Recently, free virions were discovered in plasma, which reveals a possible new mode of HTLV replication. It is unclear how this discovery might affect the routes of HTLV transmission, particularly sexual transmission, because HTLV transmission rates are significantly higher from men to women than women to men.
\end{abstract}

Keywords: Deltaretrovirus. Human T-cell lymphotropic virus type 1. Sexually transmitted diseases.

\section{INTRODUCTION}

Human T-cell lymphotropic virus type 1 (HTLV-1) and human T-cell lymphotropic virus type 2 (HTLV-2) belong to the Retroviridae family and the genus deltaretrovirus. HTLV-1 and HTLV-2 were the first retroviruses to be identified in humans ${ }^{1,2}$. Two novel viruses, human T-cell lymphotropic virus type 3 (HTLV-3) and human T-cell lymphotropic virus type 4 (HTLV-4), have recently been isolated in Central Africa; however, these viruses have not been associated with human disease ${ }^{3,4}$, and transmission among humans has not been demonstrated ${ }^{5}$.

HTLV-1 infection is endemic in many parts of world, including southwestern Japan, several Caribbean islands, South America, and locations in the Middle East and AustraloMelanesia ${ }^{6,7}$. A recent review analyzed the epidemiological data from a total population of approximately 1.5 billion individuals who were residing in HTLV-1-endemic areas; the epidemiological data from other highly populated regions such as China, India, the Maghreb, and East Africa have not been analyzed. The findings of this review suggested that there are approximately 5-10 million HTLV-1 carriers worldwide ${ }^{7}$. These results are consistent with previous estimates of 10-20 million infected individuals ${ }^{8}$. In Brazil alone, an estimated 2.5 million people are infected, which is most likely the largest number of seropositive individuals in a single country 9

\footnotetext{
Address to: Dr. Jorge Casseb. LIM56/IMT/USP. Av Dr. Enéas de Carvalho Aguiar 470/3 andar, Prédio IMT II, 05043-903 São Paulo, SP, Brasil.

Phone: 5511 3061-7199; Fax: 5511 3081-7190

e-mail: jcasseb@usp.br

Received 1 November 2013

Accepted 17 February 2014
}

The Human T-cell lymphotropic virus type (HTLV) retrovirus is the causative agent of HTLV-1-associated myelopathy/tropical spastic paraparesis (HAM/TSP), adult T-cell leukemia (ATL), uveitis, infective dermatitis, inflammatory disorders, and emerging syndromes that are associated with HTLV $^{6-9}$.

HTLV-2, despite its close relationship to HTLV-1, has distinctive pathogenesis and transmission characteristics, such as a lower provirus load ${ }^{10,11}$, a higher occurrence of pneumonia and bronchitis ${ }^{12,13}$ and a similar prevalence in males and females, which suggests that sexual transmission of the virus might be equally efficient between the sexes ${ }^{14}$. HTLV-2 is prevalent in native populations, such as indigenous peoples in the Americas and Pygmy tribes in Africa, and in intravenous drug users ${ }^{15-19}$. Despite a $65 \%$ homology with HTLV-1, HTLV-2 has not been consistently associated with human disease; however, neurological disorders similar to HAM/TSP have been observed in patients with HTLV-2 infection ${ }^{15,20}$.

Genome sequence analyses have subdivided HTLV-1 and HTLV-2 into seven and four subtypes, respectively. The subtypes do not vary in pathogenicity and most likely reflect the geographical origins and migrations of ancient populations ${ }^{21-23}$. In addition, genomic sequencing has confirmed the transmission of HTLV-1 from infected spouses to uninfected spouses by revealing identical sequences in seropositive individuals and those spouses who seroconverted ${ }^{24}$.

\section{CELL-TO-CELL SPREAD: THE HTLV-1 VIROLOGICAL SYNAPSE}

The routes of transmission of HTLV-1 and HTLV-2 are identical to those of human immunodeficiency virus (HIV); however, free infectious HTLV-1 particles are rarely found in plasma. Direct cell-to-cell contact is necessary for the efficient transmission of HTLV-1 from an infected cell to a new host cell 
via a specialized and highly organized mechanism known as the virological synapse, in which the virus subverts normal $\mathrm{T}$ cell physiology. Direct cell contact rapidly induces cytoskeleton polarization from the infected cell to the cell-cell junction. HTLV-1 core (Gag protein) complexes and the HTLV-1 genome accumulate at the cell-cell junction and are rapidly transferred to the uninfected cell, a process that requires approximately two hours ${ }^{25}$. Another possible route of in vivo intercellular HTLV-1 transmission involves the internalization of cell-free particles by dendritic cells, which are subsequently transferred to lymphocytes by cell-to-cell contact ${ }^{26}$. Additionally, virus particles might be retained on the cell surface in a biofilm-like structure before being laterally transferred to recipient cells that are outside of cell-cell contact regions ${ }^{27}$. Whereas HTLV-1 infects mobile cells (lymphocytes), the virological synapse maximizes transmission efficiency and limits virus exposure to host defense mechanisms ${ }^{28}$.

\section{MODES OF HTLV TRANSMISSION}

Human T-cell lymphotropic virus transmission primarily occurs through the following three routes: 1) vertically from mother to child during transplacental transfer, delivery, or breastfeeding; 2) sexual contact, primarily from men to women; and 3) parenterally through the transfusion of blood and blood components or through contaminated needles (Figure 1).

The limited passage of infected lymphocytes through the placenta most likely contributes to the relative rarity of

\section{Vertical (mother to child)}
A. breastfeeding
B. during delivery
C. transplacental

\section{Parenteral}

A. blood transfusion

B. injection drug use

C. organ transplantation

D. occupational accidents

E. latrogenic

F. razor blade sharing

\section{Sexual}

A. male to female

B. female to male

C. male to male

FIGURE 1 - Modes of HTLV-1 and HTLV-2 transmission.

HTLV-1/2: human T-cell lymphotropic virus types 1 and 2. transplacental HTLV-1 infection ${ }^{29,30}$; however, this type of HTLV-1 infection requires further study to evaluate its effects on the fetus, which could have implications for counseling serologically discordant couples who wish to have children. HTLV-1 transmission occurs through the transfusion of cellular blood components, which results in seroconversion in more than $40 \%$ of recipients; the transfusion of plasma or plasma derivatives does not result in seroconversion ${ }^{31}$.

The highest prevalence of HTLV has been observed in injection drug users ${ }^{32,33}$. HTLV-1 is more frequent among injection drug users in Brazil and New York ${ }^{34-38}$, whereas HTLV-2 is more prevalent in injection drug users in other locations in North America and in Europe ${ }^{39-44}$. In 2001, the first cases of HTLV-1 transmission through organs that were transplanted from asymptomatic infected donors were reported in Europe; three donor organ recipients developed subacute myelopathy shortly after transplantation ${ }^{45}$. Pepin et al. postulated that iatrogenic HTLV-1 transmission occurred during massive intramuscular pentamidine interventions to control sleeping sickness in equatorial Africa from 1947-1953 ${ }^{46}$.

Lopes ${ }^{47}$ cited research that reported possible HIV transmission between two sisters in Sydney in 2003. One sibling was infected, and the other sibling was found to be positive when donating blood. Transmission was hypothesized to have occurred through a shared razor blade. Lopes considered this route of transmission to be a risk factor for HTLV-1 transmission in blood donors; however, few studies have been conducted on this subject to support these findings ${ }^{47}$.

HTLV is present in the genital secretions of infected individuals and could be transmitted through sexual intercourse, which is the second most common mode of HTLV transmission ${ }^{48}$. Infection in endemic areas is maintained by horizontal transmission though unprotected sexual intercourse and by vertical transmission from mother to child during breastfeeding ${ }^{49}$.

\section{SEXUAL TRANSMISSION}

High-risk behaviors, such as unprotected $\operatorname{sex}^{50}$, multiple partners ${ }^{51-53}$, sexual intercourse with injection drug users ${ }^{34,39}$, sexual partners from HTLV-endemic areas ${ }^{54,55}$, certain sexual practices $^{53}$, and a history of other sexually transmitted diseases $^{50-60}$, have been identified as risk factors for HTLV infection. In addition, the epidemiology of HTLV, particularly its tendency to occur in clusters, has enabled the identification of groups who are at risk for exposure, including injection drug users $^{34,56,59}$, sex workers ${ }^{50,55-62}$, men who engage in intercourse with other men ${ }^{52,53,56}$, recipients of blood transfusions in Brazil before November $1993^{63}$, and sexual partners of known HTLV carriers $^{64-66}$ (Figure 2).

HTLV-1 is transmitted more efficiently from males to females than from females to males. Research in Japan over a 10-year period demonstrated that the rate of HTLV-1 transmission from husband to wife was $60.8 \%$, whereas the rate of transmission from wife to husband was $0.4 \%{ }^{64}$. Roucoux et al.$^{65}$ performed a prospective study of 85 couples who were serodiscordant for both viruses (30 patients with HTLV-1 and 55 patients with HTLV-2) over a 10-year period and found no significant differences in the sexual transmission rates 


\section{Sociodemographic}

A. live in or originate from an endemic area

\section{Risk-associated exposures}

A. unprotected sex

B. multiple sexual partners

C. sexual partnership with an injection drug user

D. sexual partnership with individuals from endemic areas

E. type of sexual practice

F. history of other sexually transmitted disease

\section{Risk groups for exposure}

A. injection drug users

B. sex workers

C. men who have sexual intercourse with other men D. sexual partners of known HTLV carriers

\section{Biological}

A. gender

male $>$ female

B. age

$>45$ years

C. hormonal

menopause

D. high circulating proviral load

$>60$ years

HTLV-1-associated myelopathy/

tropical spastic paraparesis

infective dermatitis

adult T-cell leukemia-lymphoma

HTLV-1 uveitis

\section{Co-infections}

A. strongyloidiasis

B. sexually transmitted disease

FIGURE 2 - Factors that might influence the risk of sexual transmission or acquisition of HTLV.

HTLV-1: human T-cell lymphotropic virus type 1. between HTLV-1 and HTLV-2 ( 0.9 and 0.4 transmissions per 100 person-years (py) for HTLV-1 and HTLV-2, respectively). The male to female transmission rate for HTLV-1/2 was 1.2 transmissions/py, whereas the female to male transmission rate was 0.4 transmissions/py.

The results of this study are in contrast to the finding of 2.5 transmissions/100py by Stuver et al. ${ }^{66}$ in a Miyazaki cohort of southeastern Japanese couples; however, Roucoux et al. included a higher number of couples with HTLV-1 infections that were, on average, much older and in longer relationships ( $>360$ vs. 72 months). Larsen et al. ${ }^{67}$ reported an overall HTLV prevalence of $3.6 \%$ ( 76 of 2,127 subjects) in an adult population living in urban areas in Guinea-Bissau, Africa, and the prevalence rates among men and women were $2.2 \%$ and $4.7 \%$, respectively. This difference increased with age ( $>44$ years).

Murphy et al. ${ }^{51}$ found lower efficiency in female-to-male HTLV-1 sexual transmission in 2,050 consecutive patients who presented with new episodes of sexually transmitted disease. Additionally, they found that penile ulcers or concurrent syphilis might increase the risk of infection in men.

In a multivariate analysis of HTLV transmission in Salvador, Bahia, Dourado et al. ${ }^{34}$ concluded that sexual transmission might play an important role in the increasing rates of HTLV transmission from men to women among intravenous drug users in endemic areas, in which HTLV infection rates remain high. They reported that the prevalence rates of HTLV-1, HTLV-2, and HIV- 1 were $22 \%, 11.3 \%$ and $44.1 \%$ among men and $46.2 \%$, $10.3 \%$, and $74.4 \%$ among women, respectively.

Gottuzo et al..$^{50}$ found that the prevalence of HTLV-1 in 400 female sex workers in Peru who were treated in clinics for sexually transmitted diseases increased with the duration of prostitution from $3.6 \%$ ( $<3$ years) to $9.3 \%$ (3-6 years) to $15.9 \%$ ( $>6$ years). Wignall et al. ${ }^{62}$ reported a $21.8 \%$ prevalence rate of HTLV-1 among prostitutes in Callao, Peru, which was correlated with the number of years of prostitution; this finding suggests an association between sexual activity and HTLV-1 transmission. Nakashima et al..$^{58}$ found a significantly higher prevalence of anti-HTLV-1 antibodies (5.1\%) in 409 female prostitutes in Kyushu, Japan than in a control group of non-prostitutes (1.3\%). Additionally, they reported that the participants, who were initially seronegative, seroconverted over the 2-year study period.

Khabbaz et al. ${ }^{59}$ found anti-HTLV-1/2 seroprevalence rates that ranged from $0 \%-25.4 \%$ among 1,305 female prostitutes from eight areas in the United States, and the overall prevalence was $6.7 \%$. In this study, HTLV- $1 / 2$ seropositivity was independently associated with race, intravenous drug use, hepatitis B seropositivity, the area of recruitment (Newark, NJ, USA), and the years of sexual activity. The authors could not differentiate between HTLV-1 and HTLV-2 seroreactivity; however, the seropositivity rate among women with no admitted intravenous drug use and no needle marks (2.4\%) was high compared with the reported rates in other groups in the USA.

Verdier et al..$^{60}$ conducted a serological survey of 3,177 Ivory Coast residents and observed an HTLV-1 prevalence of $7.4 \%$ in prostitutes. They concluded that this high HTLV-1 prevalence suggests that heterosexual contact is involved in HTLV-1 
transmission and that prostitutes might play an important role in the spread of HTVL in Africa.

The rate found by Verdier et al. ${ }^{60}$ is similar to that found by Delaporte et al..$^{57}$ in another African population in Kinshasa, Zaire. Among 1,183 prostitutes, 86 (7.3\%) were positive for HTLV-1. The seroprevalence among prostitutes from equatorial regions was $12.7 \%$ compared with $0 \%-4.3 \%$ among prostitutes from other regions. In prostitutes from high prevalence regions, HTLV-1 infection was associated with increasing age, active syphilis and HIV infection. Among women from low-prevalence regions, no significant differences in the HTLV-1 seroprevalence were found between prostitutes (4.3\%) and pregnant women (3.5\%). In 409 prostitutes who were observed for a mean duration of 23 months, the incidence of HTLV-1 infection was 0.7 per 100 women-years, whereas the incidence of HIV infection was 9.8 per 100 women-years. The authors concluded that prostitution was not associated with an increased risk of HTLV-1 infection in Kinshasa. However, these discrepancies might have been at least partially influenced by the prevalence of other sexually transmitted diseases in the study populations.

Nakashima et al. ${ }^{58}$ found a significantly higher HTLV-1 prevalence in prostitutes. Additionally, among subjects with sexually transmitted diseases, they observed that female prostitutes, female syphilis patients, male patients with nongonococcal urethritis, and female gonorrhea patients had significantly higher HTLV-l prevalence rates than that observed in the patient control group. In Peru, Gotuzzo et al. ${ }^{50}$ found that HTLV-1 seropositivity was significantly correlated with the duration of prostitution, inconsistent condom use, the presence of antibodies to herpes simplex virus type 2 (HSV-2), and prior Chlamydia trachomatis infections.

Murphy et al. ${ }^{51}$ studied 1,977 patients who visited clinics for the treatment of sexually transmitted diseases and found an overall HTLV-1 seroprevalence rate of $5.7 \%$. The prevalence of HTLV-1 was higher in female patients with sexually transmitted diseases. The independent risk factors for HTLV-1 infection in women included more than ten sexual partners in lifetime and a current diagnosis of syphilis. In men, a history of penile sores or ulcers and a current diagnosis of syphilis were independent risk factors for HTLV-1 infection. Of 1,977 patients, five (0.3\%) had antibodies to HIV-1, including two with HTLV-1 and HIV-1 co-infections.

Berini et al. ${ }^{56}$ estimated the prevalence of HTLV-1/2 infections and co-infections with HIV, hepatitis B, hepatitis C, and Treponema pallidum in five high-risk groups in Argentina. In addition, they characterized the epidemiological patterns of these infections. The high-risk groups included injection drug users, female sex workers, men who engaged in sexual intercourse with other men, patients with tuberculosis, and patients who attended clinics for sexually transmitted infections. The study yielded an overall HTLV- $1 / 2$ prevalence rate of $2.7 \%$ (56/2,055 subjects) (1.3\% and 1.4\% for HTLV-1 and HTLV-2, respectively), which was significantly higher than the prevalence rate in healthy adult volunteer blood donors from the same area of Buenos Aires (0.03\%-0.08\%). The prevalence rates of HTLV- $1 / 2$ among female sex workers, patients who sought treatment for sexually transmitted infections, and men who engaged in sexual intercourse with other men were $2.1 \%, 1 \%$ and $0.4 \%$, respectively.

In areas with a low prevalence of HTLV, a London study reported that HTLV seropositivity was up to 100 -fold greater among patients who sought clinical treatment for sexually transmitted infections than in non-infected blood donors ${ }^{54}$. No infected individuals in this study reported a history of injection drug use or blood transfusion.

HTLV-1 infection is more prevalent among men who engage in intercourse with men than among those who engage in intercourse with women, most likely because of the large numbers of lymphocytes in the gastrointestinal tract and an increased risk of mucosal injury during intercourse. The risk factors for HTLV-1 infection include older age, a greater number of male sexual partners in lifetime, and unprotected receptive anal intercourse $\mathrm{e}^{51-53}$.

To test for retroviral infections, La Rosa et al. ${ }^{52}$ performed serological analyses in 2,655 Peruvian men who engaged in intercourse with other men and who had no history of injection drug use. HTLV-1 was detected in $1.8 \%$ of the patients, and HTLV-2 was detected in $1.1 \%$ of the patients. HTLV- 1 and HTLV- 2 were detected in $0.2 \%$ of the patients. HIV was detected in $12.4 \%$ of the patients, and $7.3 \%$ of these patients had HTLV co-infections. HTLV-1 and HTLV-2 infections were associated with high-risk behaviors, syphilis, and HSV-2 infection.

There is evidence of an association between the risk of HTLV infection among men who engage in intercourse with other men and sexually transmitted diseases, including HIV infection ${ }^{52}$, HSV-2 ${ }^{52,53}$, and syphilis ${ }^{52,53}$.

High prevalence rates of HTLV-1 and HTLV-2 were observed in immigrant male-to-female transsexual sex workers from Latin America. Zehender et al. ${ }^{55}$ surveyed 393 recent European immigrants for HTLV-1 and HTLV-2 infections. Of these individuals, 167 were HIV-positive, including 52 male-to-female transsexual sex workers, and 226 were HIV-negative pregnant women. The HTLV prevalence rate in the HIV-positive group was $3.6 \%$ compared with $0.9 \%$ in the HIV-negative group. Latin Americans, particularly those born in Peru, were associated with the highest HTLV-1 prevalence in both groups. All of the HIV-1/ HTLV-1 co-infected individuals were male-to-female transsexual sex workers; the overall prevalence rate of HTLV-1 infection in this group was $11.5 \%$. HTLV-2 was only found in HIV-1-positive individuals; these infected subjects were transsexual sex workers from Brazil (an overall prevalence of 6.4\%).

Roucoux et al. ${ }^{65}$ observed lower HTLV-1/2 proviral loads in patients with sexually acquired infections compared with HTLV-1/2-positive index patients who transmitted HTLV, most likely because of the small infectious dose that is required for the sexual transmission of the virus.

In contrast to other authors, Ishak et al. ${ }^{14}$ did not find any differences in the HTLV-2 infection rates between male and female subjects (31.4\% vs. $34.2 \%)$ in the Kayapo tribe from the Brazilian Amazon region. This result is in disagreement with the evidence of more efficient viral transmission from males to females. 


\section{GENITAL EXCRETION AND VIRAL TRANSMISSION OF HTLV}

HTLV transmission might be influenced by several factors, including genitourinary HTLV shedding. Many factors are associated with HTLV shedding and the HTLV proviral load in genital (seminal and vaginal) secretions (Figure 2).

In the vertical transmission of HTLV-1, the proviral load in peripheral blood mononuclear cells is correlated with the proviral load in breast milk, and higher proviral loads increase the risk of HTLV-1 transmission ${ }^{68,69}$. Similarly, higher proviral loads in peripheral blood mononuclear cells might be associated with increased shedding of HTLV-1, which increases the risk of sexual transmission.

High HTLV-1 and HTLV-2 proviral loads have been reported to increase the risk of male-to-female HTLV-1 transmission ${ }^{65-66,70}$. In an investigation of blood donors and their stable heterosexual sexual partners, Kaplan et al. reported higher circulating proviral loads among seroconcordant couples in which the male partner had most likely transmitted the virus to his female partner than among couples with non-transmitting male partners ${ }^{70}$.

Stuver et al. ${ }^{66}$ studied 534 married couples with at least one HTLV-1-seropositive spouse. After five years of follow-up, they reported that the age of seropositive husbands (up to 60 years) was an important factor for HTLV-1 transmission to wives, possibly because of an age-related increase in viremia.

Roucoux et al. ${ }^{65}$ observed higher proviral loads in HTLVpositive index partners who transmitted HTLV than in HTLVpositive index partners who did not transmit the virus; however, the limited number of detected seroconversions suggested that this association was not statistically significant in their cohort. In contrast, a significantly lower proviral load was observed in newly infected partners, which indicates that low proviral loads in newly infected partners might be associated with a small infectious dose in the sexual transmission of HTLV.

Higher proviral loads tend to be associated with HAM/ TSP $^{71-75}$, adult T-cell leukemia-lymphoma ${ }^{76}$, HTLV-1-associated infective dermatitis ${ }^{77}$, and HTLV-1 uveitis ${ }^{78}$. HAM/TSP patients presented proviral loads in peripheral blood mononuclear cells that were 10-fold higher than those in asymptomatic HTLV-1 carriers ${ }^{71}$. Additionally, Strongyloides stercoralis infection might increase circulating HTLV-1 proviral loads ${ }^{76,79,80}$. One study reported that the proviral loads in HTLV-1 carriers with strongyloidiasis were more than five times higher than those in HTLV-1-positive individuals without strongyloidiasis, most likely because of oligoclonal expansion ${ }^{72}$. Therefore, inflammatory conditions might recruit lymphocytes to the genital tract, where they are infected with HTLV-1 particles. Conditions that are associated with an increased number of lymphocytes in cervicovaginal secretions and semen might result in an increased excretion of infected cells and a consequently higher risk of HTLV sexual transmission ${ }^{81,82}$.

Zunt et al. ${ }^{61}$ detected cervical shedding of HTLV-1 deoxyribonucleic acid (DNA) in $68 \%$ of 63 HTLV-1- infected Peruvian sex workers. HTLV-1 DNA was associated with the presence of $\geq 30$ polymorphonuclear cells (PMNs) per 100x microscopic field cervical mucus sample. The cervical shedding of HTLV DNA was observed in $81 \%$ of the samples from women with $\geq 30$ PMNs and in $49 \%$ of the samples from women with $<30$ PMNs on endocervical gram staining. In addition, shedding was associated with grossly visible cervical secretions.

The enrichment of PMNs in cervical mucus might be associated with Neisseria gonorrhoeae, C. trachomatis, or HSV cervical infections; however, Zunt et al. ${ }^{61}$ did not find statistically significant associations between $C$. trachomatis and $N$. gonorrhoeae infections, and the presence of HTLV DNA was most likely due to the small sample size in the study. Co-infections or other conditions that were not tested, such as HSV, Treponema pallidum, or Mycoplasma genitalium infections, which are known causes of ulcerations and nongonococcal cervicitis, might have been associated with the observed cervicitis. The authors did not perform colposcopies to determine the influence of cervical ectopy or other abnormalities on HTLV-1 cervical shedding. The results clearly suggest that cervicitis might increase HTLV-1 cervical shedding and sexual transmission of the virus ${ }^{61}$.

Higher concentrations of infected lymphocytes in semen than in vaginal secretions might be associated with more efficient viral transmission from men to woman. The leukocyte cut-off values in fertile men have been reported to vary from $0.5-1.0 \times 10^{6} \mathrm{PMN}$ leukocytes per $\mathrm{mL}$ and from $1-2 \times 10^{6}$ total leukocytes per $\mathrm{mL}^{83}$.

Granulocytes are the most prevalent white blood cells (WBCs) in semen (50\%-60\%), followed by macrophages (20\%-30\%) and T-lymphocytes $(2 \%-5 \%)^{83-85}$; however, the range of these subpopulations in the semen of infertile men varies widely. Approximately $50 \%$ of leukocytes are $\mathrm{T}$ cells, $28 \%$ are cluster of differentiation 4 (CD4) T lymphocytes, and $11 \%$ are cluster of differentiation 8 (CD8) T lymphocytes ${ }^{86}$. These differences might be attributed to differential exudate leukocyte compositions that are related to the type of invading pathogen or irritant, which varies among populations according to the prevalence of certain infections and exposure to toxic environmental irritants ${ }^{86}$.

HTLV-infected lymphocytes, particularly those in sperm, are considered the primary vectors of sexual transmission; however, the concurrence of genital infections and sexually transmitted diseases might facilitate viral transmission because these conditions expose target cells through genitomucosal lesions ${ }^{87}$.

Ulcerative sexually transmitted diseases, such as syphilis, HSV-2, and chancroid, cause lesions that result in the breakdown of mucosal integrity and recruit activated target cells, including an enriched population of cells that carry CD4 cell receptors. Additionally, these sexually transmitted diseases lead to a cascade of pro-inflammatory cytokines that recruit inflammatory cells to the genital tract ${ }^{83}$. The presence of other inflammationcausing sexually transmitted diseases, such as $N$. gonorrhoeae, C. trachomatis, and T. vaginalis, results in the recruitment of inflammatory cells ${ }^{88}$ and potentiates HTLV acquisition and transmission. 
The presence of anti-Tax antibodies is associated with the sexual transmission of HTLV-1. Using a Western blot assay with a recombinant Tax protein as the antigen, Chen et al. ${ }^{89}$ tested serum samples from married couples who were serologically discordant or concordant for HTLV-1. The results revealed that 24 of $32(75 \%)$ men within the concordant group (in which both the husband and wife were HTLV-1 carriers) had anti-Tax antibodies, whereas 5 of $18(27.8 \%)$ men in the discordant group (in which the husband was a carrier and the wife was seronegative for HTLV-1) were positive for anti-Tax antibodies. The spouses of the five seroconverters (four women and one man) had anti-Tax antibodies, whereas $23(50 \%)$ of 46 age-matched, randomly selected HTLV-1 carriers from the discordant couple group had anti-Tax antibodies. When the data were analyzed according to gender, all of the husbands of the female seroconverters had anti-Tax antibodies, and this prevalence was significantly higher than the prevalence of antiTax antibodies in men who did not transmit the virus to their spouses during the follow-up period $(\mathrm{p}=0.017)$.

Moriuichi et al. ${ }^{90}$ demonstrated that seminal fluid could enhance HTLV-1 replication and transmission by the transactivation of the HTLV-1 long terminal repeat promoter, which results from several bioactive factors in seminal fluid. Previously, these authors had hypothesized that prostaglandins (PGs), which are plentiful in breast milk and seminal fluid, might be involved in HTLV-1 transmission. They subsequently found that the virus interacted with and benefitted from PGs as follows: prostaglandin E2 (PGE2) enhanced HTLV-1 replication by upregulating the HTLV-1 long terminal repeat (LTR) promoter, and HTLV-1 Tax transactivated a promoter for ciclo-oxigenase-2 (COX-2), a PG synthetase, which stimulated the production of PGE2. This synergistic mechanism most likely accelerates viral transmission through seminal fluid ${ }^{91}$.

\section{A DECREASE IN HTLV-1 VIRAL SHEDDING AND A REDUCTION IN SPREAD THROUGH NATURAL BARRIERS}

The rate of sexual HTLV transmission might be influenced by factors that reduce viral excretion or hinder viral passage through natural barriers.

Belec et al. ${ }^{92}$ tested paired sera, saliva, and cervicovaginal secretions from 17 HTLV-1-infected women and found that HTLV-1 excretion elicits a weak local immune response to the infection, which might limit HTLV-1 transmission via cervicovaginal secretions. HTLV-1 DNA was detected in $24 \%$ of the saliva secretion samples, $20 \%$ of the cervicovaginal secretion samples, and all of the samples from patients who were positive for the local synthesis of HTLV-1-specific immunoglobulin A (IgA) or immunoglobulin G (IgG). Additionally, HTLV-1 antiserum, which contains high titers of anti-Env neutralizing antibodies, was a potent inhibitor in most of the assays, indicating that neutralizing antibodies in patient sera might play an important role in protection against HTLV-1 transmission, particularly if the antibodies are also at high titers in vaginal secretions. The presence of these antibodies might help limit HTLV-1 transmission via cervicovaginal secretions ${ }^{93}$.
To test the hypothesis that human foreskin susceptibility to HIV-1 infection is associated with the number of HIV-1 target cells and the expression of HIV-1 co-receptors, Patterson et al ${ }^{94}$ quantified $\mathrm{CD} 4+\mathrm{T}$ cells, macrophages, and Langerhans cells (LCs) in foreskin tissue from pediatric and adult patients without histories of sexually transmitted disease. The authors used cervical biopsies from HIV-1-seronegative women as controls and found that the adult foreskin mucosa contained higher mean proportions of CD4+ T cells (22.4\%), macrophages (2.4\%), and LCs $(11.5 \%)$ than both the foreskin mucosa of children $(4.9 \%, 0.3 \%$, and $6.2 \%)$ and cervical mucosa $(6.2 \%, 1.4 \%$, and $1.5 \%)$. Additionally, they observed that the number of target cells increased with patient age. The highest proportions of CD4+ T cells and LCs occurred in patients with a history of infection with balanitis, C. trachomatis, or genital ulcers. The majority of $T$ cells were found in the submucosa rather than in the external foreskin mucosa. These results indicate that a decrease in the number of HIV-1 target cells and an increase in external foreskin keratinization reduce susceptibility to HIV-1 infection in the outer foreskin compared with the inner surface.

Despite the lower efficiency of HTLV-1 infection compared with HIV infection, these data could theoretically be applied to HTLV-1. Similar to HIV, HTLV uses CD4 as the target cell; therefore, foreskin circumcision might have a potential protective effect against HTLV infection.

Studies on candidate topical microbicides suggest that these agents might reduce HTLV-1 sexual transmission ${ }^{93}$ and reduce circulating proviral loads without affecting host immune systems; topical microbicides are potential therapeutic agents for the prevention and treatment of HTLV-1-associated diseases ${ }^{95}$.

Approximately $80 \%$ of viral infections are initiated at mucosal surfaces, and virus particles could be retained on cell surfaces in a biofilm-like structure before transfer to cell-cell contact regions; therefore, the role of extracellular matrix components in virus transmission requires further study ${ }^{96}$.

Antiretroviral therapy is not used clinically to reduce the risk of HTLV transmission, such as in cases that result from occupational accidents, vertical transmission, or sexual violence. Few studies have evaluated potential therapies for pre- or postexposure prophylaxis against HTLV infection. Further studies are required to evaluate drug and treatment protocol efficacies for the prevention or reduction of viral transmission and cell-cell spread and to determine the treatment effects on HTLV-1 levels in genital secretions. The development of therapies to prevent horizontal and vertical transmission of HTLV is particularly important for discordant couples who wish to have children.

According to Zihlmann ${ }^{97}$, the reproductive decisions of couples are complex, and no simple guidelines are available to reduce the transmission risks for serodiscordant couples. The study by Zihlmann highlighted the recommendations from the Guia de Manejo Clínico do HTLV do Ministério da Saúde of Brazil and the recommendations by the Centers for Disease Control and Prevention in the United States. These recommendations suggest that in cases in which a sexual partner is negative, the couple should be advised to use condoms; however, no recommendations are indicated in cases in which 
both sexual partners are positive. In addition, serodiscordant couples are advised to use condoms outside the fertile period; however, condom use might be excluded during attempts to conceive.

The Ministry of Health of Brazil has recommended semen viral load determination and sperm washing as strategies to reduce the risks of sexual HIV transmission for people who live and coexist with human immunodeficiency virus/ acquired immunodeficiency syndrome (HIV/AIDS) and wish to conceive ${ }^{98}$. However, no comparable studies have measured the predictive value of the HTLV proviral load in semen in determining the risk of sexual HTLV transmission.

In HTLV infection, cell-to-cell contact and Tax-induced clonal expansion of infected cells are the primary modes of virus replication, which causes difficulty in detection of the virus during the viremic stage. Cabral et al. ${ }^{99}$ recently reported the detection of free HTLV-1 RNA in the plasma from asymptomatic HTLV-1 carriers and HAM/TSP patients. In this study, realtime polymerase chain reaction (PCR) was performed using DNA, which was isolated from 150 plasma samples from 123 HTLV-1 asymptomatic carriers and 27 HAM/TSP-positive patients. Twelve (8\%) samples had detectable HTLV-1 DNA, including six (4\%) samples from asymptomatic HTLV-1 carriers and $14(26 \%)$ samples from HAM/TSP patients $(\mathrm{p}<0.005)$. Additionally, a subset of 40 HTLV-1 ribonucleic acid (RNA) samples was amplified using nested PCR to increase the HTLV-1 detection sensitivity and specificity. Of these samples, seven were excluded from the analysis. Of the 33 remaining samples that were retro-transcribed to complementary DNA (cDNA) and amplified using nested PCR, six (18\%) samples were positive for plasma proviral RNA. This study found that free RNA could be detected in plasma samples among HTLV-1-infected subjects regardless of the clinical status, which suggests new strategies for HTLV replication. However, the effect of this phenomenon the routes of HTLV transmission, particularly sexual transmission, remains to be determined. This mode of replication might influence HTLV transmission rates, which are significantly higher in women than in men research that address these critical knowledge gaps might contribute to the prevention of HTLV transmission and to improved care for HTLV-infected individuals.

Japanese efforts have demonstrated that preventive measures, such as screening blood bank donations, counseling serodiscordant couples, and abstinence from breastfeeding by carrier mothers, might reduce the prevalence of HTLV. Several years after the commencement of the ATL Prevention Program Nagasaki in 1987, a sharp decline in the prevalence of HTLV carriers (from 20\%-25\% to 4\%) was observed in the Nagasaki population ${ }^{30}$.

\section{CONFLICT OF INTEREST}

The authors declare that there is no conflict of interest.

\section{FINANCIAL SUPPORT}

Fundação de Amparo à Pesquisa do Estado de São Paulo (FAPESP) and Fundação Faculdade de Medicina (FFM).

\section{REFERENCES}

1. Poiesz BJ, Ruscetti FW, Reitz MS, Kalyanaraman VS, Gallo RC. Isolation of a new type C retrovirus (HTLV) in primary uncultured cells of a patient with Sezary T-cell leukaemia. Nature 1981; 294:268-271.

2. Kalyanaraman VS, Sarngadharan MG, Robert-Guroff M, Miyoshi I, Golde D, Gallo RC. A new subtype of human T-cell leukemia virus (HTLV-II) associated with a T-cell variant of hairy cell leukemia. Science 1982; 218:571-573.

3. Callatini S, Chevalier SA, Duprez R, Bassot S, Froment A, Mahieux R, et al. Discovery of a new human T-cell lymphotropic virus (HTLV-3) in Central Africa. Retrovirology 2005; $2: 30$.

4. Wolfe ND, Heineine W, Carr JK, Garcia AD, Shanmugam V, Tamoufe U, Torimiro JN, et al. Emergence of unique primate T-lymphotropic viruses among central African bushmeat hunters. Proc Natl Acad Sci USA 2005; 102:7994-7999.

5. Gessain A, Rua R, Betsema E, Turpin J, Marieux R. HTLV-3/4 and simian foamy retroviruses in humans: Discovery, epidemiology, cross-species transmission and molecular virology. Virology 2013; 435:187-199.

6. Proietti FA, Carneiro-Proietti AB, Catalan-Soares BC, Murphy EL. Global epidemiology of HTLV-I infection and associated diseases. Oncogene 2005; 24:6058-6068.

7. Gesssain A, Cassar O. Epidemiological aspects and world distribution of HTLV-1 infection. Front Microbiol 2012; 3:388.

8. de Thé GD, Bomford R. An HTLV-I vaccine: why, how, for whom? AIDS Res Hum Retroviruses 1993; 9:3816.

9. Carneiro-Proietti AB, Ribas JG, Catalan-Soares BC, Martins ML, BritoMelo GE, Martins-Filho OA, et al. Infeccção e doença pelos virus linfotrópicos humanos de células T (HTLV-I/II) no Brasil. Rev Soc Bras Med Trop 2002; 35:499-508.

10. Murphy EL, Lee TH, Chafets D, Nass CC, Wang B, Loughlin K, et al. Higher Human T Lymphotropic Virus (HTLV) Provirus Load Is Associated with HTLV-I versus HTLV-II, with HTLV-II Subtype A versus B, and with Male Sex and a History of Blood Transfusion. J Infect Dis 2004; 190:504-510.

11. Montanheiro P, Olah I, Fukumori LMI, Smidb J, Penalva de Oliveira AC, Kanzaki LIB, et al. Low DNA HTLV-2 proviral load among women in São Paulo City. Virus Research 2008; 135:22-25.

12. Murphy EL, Wang B, Sacher RA, Fridey J, Smith JW, Nass CC, et al. Respiratory and urinary tract infections, arthritis, and asthma associated with HTLV-I and HTLV-II infection. Emerg Infect Dis 2004; 10:109-116.

13. Beilke MA, Theall KP, O’Brien M, Clayton JL, Benjamin SM, Winsor EL, et al. Clinical outcomes and disease progression among patients coinfected with HIV and Human T Lymphotropic Virus Types 1 and 2. CID 2004; 39:253-256.

14. Ishak R, Harrington Jr WJ, Azevedo VN, Eiraku N, Ishak MO, Guerreiro $\mathrm{JF}$, et al. Identification of human $\mathrm{T}$ cell lymphotropic virus type IIa infection in the Kayapo, an indigenous population of Brazil. AIDS Res Hum Retroviruses 1995; 11:813-821.

15. Hall WW, Ishak R, Zhu SW, Novoa P, Eiraku N, Takahashi H, et al. Human T lymphotropic virus type II (HTLV-II): epidemiology, molecular properties, and clinical features of infection J Acquir Immune Defic Syndr Hum Retrovirol 1996; 13:204-214.

16. Shindo N, Alcantara LCJ, Van Dooren S, Salemi M, Costa MCR, Kashima S, et al. Human Retroviruses (HIV and HTLV) in Brazilian Indians: Seroepidemiological Study and Molecular Epidemiology of HTLV Type 2 Isolates AIDS Res Hum Retroviruses 2002; 18:71-77. 
17. Ishak R, Vallinoto ACR, Azevedo VN, Ishak MOG. Epidemiological aspects of retrovirus (HTLV) infection among Indian populations in the Amazon Region of Brazil Cad Saude Publica 2003; 19:901-914.

18. Menna-Barreto M, Bender AL, Bonatto SL, B. Freitas LB, Salzano FM, Tsuneto LT, et al. Human T-cell lymphotropic virus type II in Guaraní Indians, Southern Brazil Cad Saude Publica 2005; 21:1947-1951.

19. Carneiro-Proietti ABF, Catalan-Soares BC, Castro-Costa CM, Murphy EL, Sabino EC, Hisada M, et al. HTLV in the Americas: challenges and perspectives. Rev Panam Salud Publica 2006; 19:44-53.

20. Araujo A, Hall WW. Human T-lymphotropic virus type II and neurological disease. Ann Neurol 2004; 56:10-19.

21. Komurian F, Pelloquin F, de Thé G. In vivo genomic variability of human T-cell leukemia virus Type I depends more upon geography than upon pathologies. J Virol 1991; 65:3770-3778.

22. Segurado AA, Biasutti C, Zeigler R, Rodrigues C, Damas CD, Jorge ML, et al. Identification of human T-lymphotropic virus type I (HTLV-I) subtypes using restricted fragment length polymorphism in a cohort of asymptomatic carriers and patients with HTLV-I-associated myelopathy/tropical spastic paraparesis from São Paulo, Brazil. Mem Inst Oswaldo Cruz 2002; 97:329-333.

23. Kashima S, Alcantara LC, Takayanagui OM, Cunha MA, Castro BG, Pombo-de- Oliveira MS, et al. Distribution of human T cell lymphotropic virus type 1 (HTLV-1) subtypes in Brazil: Genetic characterization of LTR and tax region. AIDS Res Hum Retroviruses 2006; 22:953-959.

24. Iga M, Okayama A, Stuver S, Matsuoka M, Mueller N, Aoki M, et al. Genetic evidence of transmission of Human T Cell Lymphotropic Virus Type 1 between spouses. J Infect Dis 2002; 185:691-695.

25. Igakura T, Stinchcombe JC, Goon PK, Taylor GP, Weber JN, Griffiths GM, et al. Spread of HTLV-I between lymphocytes by virus-induced polarization of the cytoskeleton. Science 2003; 299:1713-1716.

26. Jones KS, Petrow-Sadowski C, Huang YK, Bertolette DC, Ruscetti FW. Cell-free HTLV-1 infects dendritic cells leading to transmission and transformation of CD4(+) T cells. Nat Med 2008; 14:429-436.

27. Pais-Correia AM, Sachse M, Guadagnini S, Robbiati V, Lasserre R, Gessain A, et al. Biofilm-like extracellular viral assemblies mediate HTLV-1 cell-to-cell transmission at virological synapses. Nat Med 2010; 16:83-89.

28. Sattentau Q. Avoiding the void: cell-to-cell spread of human viruses. Nat Rev Microbiol 2008; 6:815-826.

29. Fujino T, Nagata Y. HTLV-I transmission from mother to child. J of Reprod Immunol 2000; 47:197-206.

30. Hino S. Establishment of the milk-borne transmission as a key factor for the peculiar endemicity of human T-lymphotropic virus type 1 (HTLV-1): the ATL Prevention Program Nagasaki. Proc Jpn Acad Ser B Phys Biol Sci 2011; 87:152-166.

31. Manns A, Wilks RJ, Murphy EL, Haynes G, Figueroa JP, Barnett M, et al. A prospective study of transmission by transfusion of HTLV-I and risk factors associated with seroconversion. Int J Cancer 1992; 51:886-891.

32. Feigal E, Murphy E, Vranizan K, Bacchetti P, Chaisson R, Drummond JE, et al. Human T cell lymphotropic virus types I and II in intravenous drug users in San Francisco: risk factors associated with seropositivity. J Infect Dis 1991; 164:36-42.

33. Khabbaz RF, Oronato IM, Cannon RO, Hartley TM, Roberts B, Hosein B, et al. Seroprevalence of HTLV-1 and HTLV-2 among intravenous drug users and persons in clinics for sexually transmitted diseases. N Engl J Med 1992; 326:375380.

34. Dourado I, Andrade T, Galvao-Castro B. HTLV-I in Northeast Brazil: Differences for male and female injecting drug users. J Acquir Immune Defic Syndr Hum Retrovirol 1998; 19:426-429.

35. Ehrlich GD, Glaser JB, LaVigne K, Quan D, Mildvan D, Sninsky JJ, et al. Prevalence of human T-cell leukemia/lymphoma virus (HTLV) type II infection among high-risk individuals: type-specific identification of HTLVs by polymerase chain reaction. Blood 1989; 74:1658-1664.

36. Lee HH, Weiss S, Brown L, Mildvan D, Shorty V, Saravolatz L, et al. Patterns of HIV-1 and HTLV-I/II in intravenous drug abusers from the middle Atlantic and central regions of the USA. J Infect Dis 1990; 162:347-352.
37. Caterino-de-Araujo A, Casseb JS, Neitzert E, de Souza ML, Mammano F, Del Mistro A, et al. HTLV-I and HTLV-II infections among HIV-1 seropositive patients in Sao Paulo, Brazil. Eur J Epidemiol 1994; 10: 165-171.

38. Etzel A, Shibata GY, Rozman M, Jorge ML, Damas CD, Segurado AA. HTLV-1 and HTLV-2 infections in HIV-infected individuals from Santos, Brazil: seroprevalence and risk factors. J Acquir Immune Defic Syndr 2001; 26:185-190.

39. Guimarães ML, Bastos FI, Telles PR, Galvão-Castro B, Diaz RS, Bongertz V, et al. Retrovirus infections in a sample of injecting drug users in Rio de Janeiro City, Brazil: Prevalence of HIV-1 subtypes, and co-infection with HTLV-I/II. J Clin Virol 2001; 21:143-151.

40. Lee H, Swanson P, Shorty VS, Zack JA, Rosenblatt JD, Chen IS. High rate of HTLV-II infection in seropositive i.v. drug abusers in New Orleans. Science 1989; 244:471-475.

41. Zella D, Mori L, Sala M, Ferrante P, Casoli C, Magnani G, et al. HTLV-II infection in Italian drug abusers. Lancet 1990; 336:575-576.

42. Lowis G, Sheremata W, Minagar A. Epidemiologic features of HTLV-II: Serologic and molecular evidence. Ann Epidemiol 2002; 12:46-66.

43. Roucoux DF, Murphy EL. The epidemiology and disease outcomes of Human T-Lymphotropic Virus type II. AIDS Review 2004; 6:144-154.

44. Toro C, Rodes B, Bassani S, Jimenez V, Tuset C, Brugal MT, et al. Molecular epidemiology of HTLV-2infection among intravenous drug users in Spain. J Clin Virol 2005; 33:65-70.

45. Toro C, Benito R, Aguilera A, Bassani S, Rodriguez C, Calderon E, et al. Infection with human T-lymphotropic virus type I in organ transplant donors and recipients in Spain. J Med Virol 2005; 76:268-270.

46. Pépin J, Labbé AC, Mamadou-Yaya F, Mbélesso P, Mbadingai S, Deslandes $\mathrm{S}$, et al. Iatrogenic transmission of human $\mathrm{T}$ cell lymphotropic virus type 1 and hepatitis $\mathrm{C}$ virus through parenteral treatment and chemoprophylaxis of sleeping sickness in colonial Equatorial Africa. Clin Infect Dis 2010; 51:777-784.

47. Lopes BP. Avaliação dos fatores de risco associados à transmissão do HTLV-1 e do HTLV-2, em doadores de sangue, na cidade de Belém. Dissertação de Mestrado; 2006. p. 105.

48. World Health Organization. Biological agents. A review of human carcinogens. IARC Monogr Eval Carcinog Risks Hum 2012; 100:1-441.

49. Catalan-Soares BC, Proietti FA, Carneiro-Proietti AB. Os virus linfotrópicos de células T humanos (HTLV) na última década (19902000): aspectos epidemiológicos. Rev Bras Epidemiol 2001; 4:81-95.

50. Gotuzzo E, Sanchez J, Escamilla J, Carrillo C, Phillips IA, Moreyra L, et al. Human T cell lymphotropic virus type I infection among female sex workers in Peru. J Infect Dis 1994; 169:754-759.

51. Murphy EL, Figueroa JP, Gibbs WN, Brathwaite A, Holding-Cobham M, Waters D, et al. Sexual transmission of human T-lymphotropic virus type I (HTLV-I). Ann Intern Med 1989; 111:555-560.

52. La Rosa AM, Zunt JR, Peinado J, Lama JR, Ton TG, Suarez L, et al. Retroviral infection in Peruvian men who have sex with men. Clin Infect Dis 2009; 49:112-117.

53. Zunt J, La Rosa AM, Peinado J, Lama JR, Suarez L, Pun M, et al. Risk factors for HTLV-II infection in Peruvian men who have sex with men. Am J Trop Med Hyg 2006; 74:922-925.

54. Turner CG, Cohen CE, Sabin CA, Tosswill JH, Best JM, Taylor GP, et al. The seroepidemiology of human T cell lymphotropic virus-I (HTLV-I) amongst genitourinary medicine attendees in South East London. 14 Annual Conference of the British HIV Association. Abstract $\mathrm{n}^{\circ}$ P47. HIV Med 2008; 9 (suppl 1):22.

55. Zehender G, Colasante C, De Maddalena C, Bernini F, Savasi V, Persico T, et al. High prevalence of human T-lymphotropic virus type 1 (HTLV-1) in immigrant male-to-female transsexual sex workers with HIV-1 infection. J Med Virol 2004; 74:207-215.

56. Berini CA, Pando MA, Bautista CT, Eirin ME, Martinez-Peralta L, Weissenbacher M, et al. HTLV-1/2 among high-risk groups in Argentina: molecular diagnosis and prevalence of different sexual transmitted infections. J Med Virol 2007; 79:1914-1920. 
57. Delaporte E, Buvé A, Nzila N, Goeman J, Dazza MC, Henzel D, et al. HTLV-I infection among prostitutes and pregnant women in Kinshasa, Zaire: how important is high-risk sexual behavior? J Acquir Immune Defic Syndr Hum Retrovirol 1995; 8:511-515.

58. Nakashima K, Kashiwag S, Kajiyam W, Hirata M, Hayash J, Noguchi A, et al. Sexual transmission of human T-lymphotropic virus type I among female prostitutes and among patients with sexually transmitted diseases in Fukuoka, Kyushu, Japan. Am J Epidemiol 1995; 141:305-331.

59. Khabbaz RF, William W, Darrow WW, Hartley TM, Witte J, Cohen JB, et al. Seroprevalence and risk factors for HTLV-I/II infection among female prostitutes in the United States. JAMA 1990; 263:60-64.

60. Verdier M, Denis F, Sangare A, Barin F, Gershy-Damet G, Rey JL, et al. Prevalence of antibody to human T cell leukemia virus type 1 (HTLV-1) in populations of Ivory Coast, West Africa. J Infect Dis 1989; 160: 363-370.

61. Zunt JR, Dezzutti CS, Montano SM, Thomas KK, Alarcon JO, Quijano E, et al. Cervical shedding of human T cell lymphotropic virus type $\mathrm{I}$ is associated with cervicitis. J Infect Dis 2002; 186:1669-1672.

62. Wignall FS, Hyams KC, Phillips IA, Escamilla J, Tejada A, Li O, et al. Sexual transmission of human T-lymphotropic virus type I in Peruvian prostitutes. J Med Virol 1992; 38:44-48.

63. Ministério da Saúde. Portaria No 1.376, de 19 de Novembro de 1993. Aprova alterações na Portaria no 721/GM, de 09.08.89, que aprova Normas Técnicas para coleta, processamento e transfusão de sangue, componentes e derivados, e dá outras providências. DOU de 02/12/1993.

64. Kajiyma W, Kachiwagi S, Ikematsu H, Hayashi J, Nomura H, Okochi K. Intrafamilial transmission of adult T-cell lleukemia virus. J Infect Dis 1986; 154:851-857.

65. Roucoux DF, Wang B, Smith D, Nass CC, Smith J, Hutching ST, et al. A prospective study of sexual transmission of human $\mathrm{T}$ lymphotropic virus (HTLV)-I and HTLV-II. J Infect Dis 2005; 191:1490-1497.

66. Stuver SO, Tachibana N, Okayama A, Shioiri S, Tsunetoshi Y, Tsuda K, et al. Heterosexual transmission of human $\mathrm{T}$ cell leukemia/lymphoma virus type I among married couples in southwestern Japan: an initial report from the Miyazaki Cohort Study. J Infect Dis 1993; 167:57-65.

67. Larsen O, Andersson S, da Silva Z, Hedegaard K, Sandstrom A, Naucler A, et al. Prevalences of HTLV-1 infection and associated risk determinants in an urban population in Guinea-Bissau, West Africa. J Acquir Immune Defic Syndr 2000; 25:157-163.

68. Hisada M, Maloney EM, Sawada T, Miley WJ, Palmer P, Hanchard B, et al. Virus markers associated with vertical transmission of human $\mathrm{T}$ lymphotropic virus type 1 in Jamaica. Clin Infect Dis 2002; 34: 1551-1557.

69. Li HC, Biggar RJ, Miley WJ, Maloney EM, Cranston B, Hanchard B, et al. Provirus load in breast milk and risk of mother-to-child transmission of human T lymphotropic virus type I. J Infect Dis 2004; 190:1275-1278.

70. Kaplan JE, Khabbaz RF, Murphy EL, Hermansen S, Roberts C, Lal R, et al. Male-to-female transmission of human T-cell lymphotropic virus types I and II: association with viral load. J Acquir Immune Defic Syndr Hum Retrovirol 1996; 12:193-201.

71. Nagai M, Usuku K, Matsumoto W, Kodama D, Takenouchi N, Moritoyo T, et al. Analysis of HTLV-I proviral load in $202 \mathrm{HAM}$ /TSP patients and 243 asymptomatic HTLV-I carriers: high proviral load strongly predisposes to HAM/TSP. J Neurovirol 1998; 4:586-593.

72. Silva MT, Harab RC, Leite AC, Schor D, Araujo A, Andrada-Serpa MJ. Human T Lymphotropic Virus Type 1 (HTLV-1) Human T lymphotropic virus type 1 (HTLV-1) proviral load in asymptomatic carriers, HTLV-1associated myelopathy/tropical spastic paraparesis, and other neurological abnormalities associated with HTLV-1 infection. Clin Infect Dis 2007; 44:689-692.

73. Yamano Y, Nagai M, Brennan M, Mora CA, Soldan SS, Tomaru U, et al. Correlation of human T-cell lymphotropic virus type 1 (HTLV-1) mRNA with proviral DNA load, virus-specific CD8+ T-cells, and disease severity in HTLV-1-associated myelopathy (HAM/TSP). Blood 2002; 99:88-94.

74. Montanheiro PA, Oliveira AC, Posada-Vergara MP, Milagres AC, Tauil C, Marchiori PE, et al. Human T-cell lymphotropic virus type I (HTLV-I) proviral DNA viral load among asymptomatic patients and patients with HTLV-I-associated myelopathy/tropical spastic paraparesis. Braz J Med Biol Res 2005; 38):1643-1647.

75. Starling AL. Perfil de citocinas plasmáticas e dosagem da carga proviral em indivíduos infectados pelo HTLV-1: estudo comparativo entre portadores assintomáticos e pacientes com HAM/TSP. Tese Mestrado Faculdade de Medicina da Universidade Federal de Minas Gerais; 2010. p. 75.

76. Iwanaga M, Watanabe T, Utsunomiya A, Okayama A, Uchimaru K, Ki-Ryang Koh KR, et al. Human T-cell leukemia virus type I (HTLV-1) proviral load and disease progression in asymptomatic HTLV-1 carriers: a nationwide prospective study in Japan. Blood 2010; 116:1211-1219.

77. Primo J, Siqueira I, Nascimento MC, Oliveira MF, Farre L, Carvalho EM, et al. High HTLV-1 proviral load, a marker for HTLV-1 associated myelopathy/tropical spastic paraparesis, is also detected in patients with infective dermatitis associated with HTLV-1. Braz J Med Biol Res 2009; 42:761-764.

78. Sugimoto M, Mita S, Tokunaga M, Yamaguchi K, Cho I, Matsumoto M, et al. Pulmonary involvement in human T-cell lymphotropic virus type-I uveitis: Tlymphocytosis and high proviral DNA load in bronchoalveolar lavage fluid. Eur Respir J 1993; 6:938-943.

79. Maloney EM, Hisada M, Palmer P, Brooks K, Pate E, Wiktor SZ, et al. Human T cell lymphotropic virus type I-associated infective dermatitis in Jamaica: a case report of clinical and biologic correlates. Pediatr Infect Dis J 2000; 19:560-565.

80. Gabet AS, Mortreux F, Talarmin A, Plumelle Y, Leclercq I, Leroy A, et al. High circulating proviral load with oligoclonal expansion of HTLV1 bearing T cells in HTLV-1 carriers with strongyloidiasis. Oncogene 2000; 19:4954-4960.

81. Pique C, Jones KS. Pathways of cell-cell transmission of HTLV-1. Front Microbiol 2012; 3:378.

82. Lairmore MD, Anupam R, Bowden N, Haines R, Haynes RA, Ratner L, et al. Molecular determinants of human T-lymphotropic virus type 1 transmission and spread. Viruses 2011; 3:1131-1165.

83. World Health Organization. $5^{\text {th }}$ ed. Geneva: World Health Organization; WHO Laboratory Manual for the Examination and Processing of Human Semen. 2010.

84. Andrade-Rocha FT, Carvalho PP. O papel do exame do sêmen na infertilidade masculina. I- Análise das características dos espermatozóides e de suas células precursoras. Rev Bras An Clin 1996; 28:171-178.

85. Wolff $\mathrm{H}$. The biologic significance of white blood cells in semen. Fertil Steril 1995; 63:1143-1157.

86. Perez WQ, Sanchez LM, Hernandez IB, Yanez LA, Perez JC, Macias DI. Characterization of mononuclear cells in non-fertile men's sperm. Rev Ciencias Medicas 2007; 11:28-34.

87. Mylonas I, Bruning A, Kainer F, Friese K. HTLV infection and its implication in gynaecology and obstetrics. Arch Gynecol Obstet 2010; 282:493-501.

88. Mayer KH, Venkatesh KK. Interactions of HIV, other sexually transmitted diseases, and genital tract inflammation facilitating local pathogen transmission and acquisition. Am J Reprod Immunol 2011; 65:308-316.

89. Chen YM, Okayama A, Lee TH, Tachibana N, Mueller N, Essex M. Sexual transmission of human T-cell leukemia virus type I associated with the presence of anti- Tax antibody. Proc Natl Acad Sci U S A 1991; 88:1182-1186.

90. Moriuchi M, Moriuchi H. Seminal Fluid Enhances Replication of Human T-Cell Leukemia Virus Type 1: Implications for Sexual Transmission. J Virol 2004; 78:12709-12711.

91. Moriuchi M, Inoue H, Moriuchi H. Reciprocal Interactions between Human T-Lymphotropic Virus Type 1 and Prostaglandins: Implications for Viral Transmission. J Virol 2001; 75:192-198.

92. Bélec L, Georges AJ, Hallouin MC, Mohamed AS, Morand-Joubert L, Georges- Courbot M. Human T-lymphotropic virus type I excretion and specific antibody response in paired saliva and cervicovaginal secretions. AIDS Res Hum Retrovir 1996;12:157-167. 
93. Romer D, Brighty DW, Robson CL, Quentin J, Sattentau QJ. Candidate polyanionic microbicides inhibit human T-cell lymphotropic virus type 1 receptor interactions, cell-free infection, and cell-cell spread. Antimicrob Agents Chemother 2009; 53:678-687.

94. Patterson BK, Landay A, Siegel JN, Flener Z, Pessis D, Chaviano A, et al. Susceptibility to human immunodeficiency virus- 1 infection of human foreskin and cervical tissue grown in explant culture. Am J Pathol 2002; 161:867-873.

95. Araya N, Takahashi K, Sato T, Nakamura T, Sawa C, Hasegawa D, et al. Fucoidan therapy decreases the proviral load in patients with human T-lymphotropic virus type-1- associated neurological disease. Antivir Ther 2011; 16:89-98.

96. Jin J, Nathan Sherer N, Mothes W. Surface Transmission or Polarized Egress? Lessons Learned from HTLV Cell-to-Cell Transmission. Viruses 2010; 2:601-605.
97. Zihlmann KF. Da invisibilidade á visibilidade do sujeito vivendo com a infecção/doena do virus linfotrópico de células T humanas do tipo 1 (HTLV-1) e o lugar das decisões reprodutivas nas tramas do saber e do cuidar. Tese de Doutorado Faculdade de Saúde Pública da Universidade de São Paulo; 2009. p. 367.

98. Ministério da Saúde. Coordenação Nacional de DST, AIDS e Hepatites Virais. Guia do Manejo Clínico do HTLV. Brasilia - DF, 2003.

99. Cabral F, Arruda LB, de Araujo ML, Montanheiro P, Smid J, de Oliveira AC, et al. Detection of human T-cell lymphotropic virus type 1 in plasma samples. Virus Res 2012; 163:87-90. 